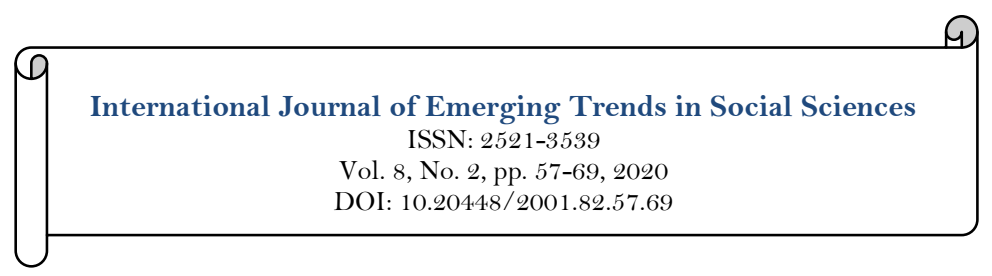

\title{
Informal Sector and Tax Compliance in Nigeria- Challenges and Opportunities
}

\author{
Adekoya, A. Augustine ${ }^{1^{*}}$ \\ Olaoye, A. Samuel ${ }^{2}$ \\ Lawal, A. Babatunde ${ }^{3}$ \\ ${ }^{1,2}$ Department of Accounting, Babcock University, Ilisan-Remo, Ogun State, Nigeria. \\ ${ }^{2}$ Email:sanyaaustineos@yahoo.com \\ ${ }^{s}$ Department of Accounting and Finance, McPherson University, Seriki-Sotayo, Ogun State, Nigeria.
}

\begin{tabular}{l|l} 
Abstract & \\
Taxing the Informal Sector (IS) and its taxpayers' compliance level has & Keywords: \\
become a focus of attention in recent times by scholars and policy makers & Accountability \\
because of IS contribution to the country. IS seems difficult to tax because of & Informal sector \\
administrative problems, human capital and personnel shortage, lack of & Tax compliance \\
record keeping, nature of its economic activities and cost implications. & Tax laws \\
Therefore, there is need for better understanding of the concept, challenges, & Transparency. \\
and methods of taxing, and of promoting tax compliance (TC) in the IS. It & \\
is against this background that the study examined IS and TC in Nigeria & Licensed: \\
with its challenges and opportunities. Exploratory research design was & This work is licensed under a \\
adopted for the study with focus on literatures in the area of taxation, & Creative Commons Attribution 4.0 \\
accounting and finance. The study concluded that taxing the IS is very & License. \\
important to any developing country as this achieved three things: revenue, & Publisher: \\
growth and governance. Government needs to expand its tax net with much & Scientific Publishing Institute \\
focus on the IS as any further neglect of this sector might dampen the moral & Accepted: 26 May 2020 \\
of some individual taxpayers especially those in the formal sector who had & Published: 15 June 2020 \\
been voluntarily paying tax. However, there is need for simplification of tax & \\
laws and establishment of tax courts, tax education and enlightenment, & \\
inter-agency collaboration and provision of Tax Identification Number & \\
(TIN), government should also exhibit accountability and transparency in & \\
order to build trust in the informal sector operators for tax compliance. &
\end{tabular}

Funding: This study received no specific financial support.

Competing Interests: The authors declare that they have no competing interests.

\section{Introduction}

Tax is an important tool for economic building and achieving sustainable development in a country. Taxation and individual tax compliance research, is of economic, political and social benefit to the citizens, policy makers, scholars and the government. Tax is a compulsory levy imposed by constituted authority on individual incomes or business enterprises profits. It is a form of payment by citizens to support and augment the cost of governance (Adekoya, Oyebamiji, \& Lawal, 2019). Tax is a form of fiscal social contract between the citizens and the government where the citizens pay tax to the government in exchange for infrastructural developments, economic and social services, maintenance of laws and orders and other administrative services rendered by the government for the well-being of the citizens. The formal sector which in most cases the focus of government for tax revenues, in recent time, had started to contributes little tax revenues to the government due to economic depression and tax equity problems, in addition with increase in government expenditures, there is need to consider informal sector taxation to enhance government revenues, address tax equity problems and increase the level of tax compliance in developing countries, especially Nigeria. Taxing the informal sector for purpose of increasing the level of tax compliance and revenues has become a focus of 
attention in recent times. Informal sector seems difficult to tax because of administrative problems, shortage of tax expertise or personnel, the nature of economic activities involved and cost implication. Informal sector taxation is of greater benefit to the country and its economy in three ways; as means of revenue generation, enhancement of economic growth and avenue for good governance.

Torgler (2003) and Terkper (2003) opined that taxing the informal sector will enhance tax morale and contribute to increase in the level of tax compliance among the prospective taxpayers. In line with this, Feld and Frey (2002) defined tax morale as the intrinsic motivation or attitude, which is the basis by which citizens provides correct statement of affairs of business activities that will enhance voluntary compliance. The essence of this is to achieve increase in government revenues as informal sector forms the largest number of contributor to Gross Domestic Products (GDP) of a country, and it also form a better sources of revenues to the government. The growth factor will aid the process of backing and assistance by government in ensuring that the informal sector grow and transform to formal sector. The avenue for good governance is based on the premise that tax payment by the informal sector will bring about social and economic relationships with the government which will enhance good governance and also ensure transparency and accountability.

Informal sectors are economics activities undertaken outside government registration, regulation and extant laws. Transaction within the sector are predominantly carried out in cash with less accounting records and bookkeeping of the daily economic activities or transactions. Lack of accounting records had posed difficulties in taxing the informal sectors incomes or profits from business transactions. Although these incomes or profits derived from business activities contribute a greater percentage to the Gross Domestic Product of a nation. Informal economy strives when there is high level of unemployment, poverty and closure of formal business as a result of economic melt-down and depression, at least $70 \%$ of informal businesses are established due to these problems. According to ILO (1972) informality is defined as a manner of doing things and this is driven by seven characteristics, which are family ownership form of business, small scale business operation, easy form of entry and exist, reliance on indigenous and local resources, the business so rely more on labour and primitive technology, and the businesses are not regulated, with much more competitive markets. The informal economy had been referred to by other authors as shadow economy, black market, underground economy, under the table, working for cash and off the books.

In Sub-Saharan Africa economies, informal sector dominate the economies as it represent 72 percent of non-agricultural employment, and it also contributed to poverty reduction in the countries (ILO, 2002). In developing countries, informal sector is the major driver of the nation's overall economy as it has the majority of skilled and unskilled workers. ILO (2014) reported that informal sector employment percentage in India, South Asia and Mali, Bolivia, East and South East Asia, Latin America, Easter Europe and Central Asia are $83.5 \%, 82 \%, 75 \%, 65 \%, 51 \%$, and $10 \%$ respectively. Informal sector is also characterized as a form of business that lack formal registration with constituted authorities. The sector carried out economic activities which in most cases operated outside the preview of government laws and regulations. It is also known as hard to tax sector of the economy. The activities of the sector at time are hard and cumbersome to measure as most of the business transactions are done in cash basis and lack proper accounting and record keeping.

Joshi, Prichard, and Heady (2014) opined that informal sector is seen as a type of business in subsistent economy. In Ghana, informal sector has $86 \%$ of labour employment and $42 \%$ contribution to the nation GDP (Mahadea \& Zogli, 2018). In Nigeria, informal sector also contribute a lot to the country's GDP and has continue to act as avenue for job creation than the formal sector. According to National Bureau of Statistics (2016) the share of informal sector to GDP in percentage, in respect of agriculture, arts, entertainment and recreation, real estate, trade, accommodation, food and service, water supply, sewage and waste management, administrative and support service, transportation and storage are $91.85 \%, 89.1 \%, 64.7 \%, 55.7 \%, 52.1 \%, 34.6 \%$, $47.1 \%$ and $18.1 \%$ respectively with overall GDP percentage of $41.43 \%$. The significant growth in numbers of informal sector in most developing countries can be attributed to high rate of unemployment in the formal sector, depressed economy and infrastructure decay. This means, entry into informal sector is driven by survival mechanism for many operators in response to solving unemployment and poverty. Taking the rate of unemployment in the country into consideration with continuous closure of some of the formal sector business outfit, Nigerians are blessed with creativity ideas and innovation of doing things rather than being idle and remain as unemployed individual. This zeal has been applied in many instances for the formation of small and medium scale enterprises. On the part of the government, the major challenge is taxing this laudable operators in the informal sector and bringing them into the tax net for purpose of increasing the country's tax revenues and level of tax compliance.

Developing countries are faced with fund problems for executing programmes and provision of social, economic and infrastructural development. This was affirmed by Obara and Nangih (2017) that developing countries faced shortage or problems of fund in achieving their financial expenditures. Dube and Casale (2016) also reported that in some Sub-Sahara African countries, there are challenges of capturing the informal and formal taxpayers into the country's tax net. This had resulted into loss of tax revenues, as a result of high level of tax evasion by taxpayers, this affects the operation and performance of government in providing the required public goods and services for the citizens. Torgler (2003b) reported that tax evasion is not a new phenomenon as it has been from the inception of taxation and this has continued to be till date. Likewise, 
according to Slahaan (2012) tax cheating is also not a new concept in the world, as it is as old as the tax laws. The reason for this is that while the government strives to collect taxes from the citizens, some of the citizens on their own will take some steps to evade tax by under reporting their incomes or statement of affairs to tax authorities for purpose of tax assessment (Williams \& Krasniqi, 2017). Nigeria as a nation, is not an exception to this problems, in addition with the fact that Nigeria is a mono-cautionary economy solemnly depending on revenue from crude oil. In the past and also at present, almost ninety percent of the nation revenue is derived from sales of crude oils and this is the bulk of revenues used in financing most of the current and capital expenditure as highlighted in the annual budget of the federal and the states. The recent down turn in the price of the crude oils in the global market coupled with, COVID-19 pandemic, in addition to the high interest rate, inflation, disruption of global supply chains, business downturn and liquidation, international and local trade restriction, and high level of unemployment, all these has created a gap between the revenues and costs of achieving the infrastructure needs of the citizens. These had been a challenge to nation's economic growth and developments. In order to raise the revenues bar of the government and achieved the expenditures need of the government, there is need to focus on taxes with intent of widening the tax net.

The area of focus which had been neglected for years as untapped is the informal sectors. There had been less tax compliance from this sector, even with the fact that the sector in most developing countries dully contributes to the countries' economy in form of its contribution to Gross Domestic Products (GDP), World Bank estimated that this contribution accounts for $40 \%$ of GDP in low income countries. The Nigerian tax policy of 2017 also confirmed that informal sector tax compliance is a major challenge in the Nigerian tax system, even with their large numbers, the level of non-compliance to tax payment is alarming. Therefore, taxing the informal sector in Nigeria will be a good development and probably achieved three things, these are enhancing the internally generated revenues, achieving economic growth and thirdly, provision of quality public governance. Therefore, government required to expand its tax net with much focus on the informal sector, any further neglect of this sector for tax revenues generation might dampen the moral of some individual taxpayers, especially those in the formal sector, who had been willingly and regularly paying tax. The objective of the papers is to add to the existing debate on tax compliance in the informal sector, identify the various challenges and opportunities available and draw conclusion on the importance and new approach for enhancement of tax compliance in the informal sector.

\section{Review of Literature}

\subsection{Conceptual Review}

Tax: The literary meaning of tax is the same to every individual, but its definition differs based on individual perceptions. To the government, tax is seen as a source of revenue, to company, it is regarded as a cost, and to individual, it is seen as depletion of income (Olowookere \& Fasina, 2013). Federal Ministry of Finance (2017) through the revised National Tax Policy defined tax as any compulsory payment made to the government, as imposed by law, without any form of direct benefit or return of value or service whether it is called a tax or not. This definition shows that for any payment to the government to be termed as tax, it must have three elements which are element of compulsory payment, element of law backing and element of nondirect benefit or return of value or service. This affirms that tax payment is not a voluntary gift, donation or contribution but it is an enforced payment backed by law and enforced by government.

In Nigeria, National Tax Policy of 2012, which was revised in 2016 and approved by the Federal Executive Council (FEC) on $1^{\text {st }}$ February, 2017 was designed to address Nigerian tax system in areas such as institutional, structural and other inherent problems prevailing in the Nigeria tax system. Tax system plays three important roles in a country, these are firstly, as a means of revenue generation - this is the basic role and most obvious reason of taxation. According to Keen (2012) tax revenue is used mostly for financing developmental, economic, social projects and other government programmes and services as highlighted in the annual budget. Secondly, is also used to lessen inequality among the citizens, by bridging the income gap and eradication of poverty through the provision of public goods (Cobham, 2005) and thirdly, by promoting good governance through institutions building, transparency and accountability.

Tax compliance: Tax compliance is defined as the extent at which the taxpayers obliged to tax obligation as at when due, along with prompt payment of tax liabilities, according to the relevant tax laws or regulations. This means the timely submission of appropriate tax information and settlement of tax liabilities to the relevant tax authority in line with the extant tax laws and formats. Tax compliance study in modern-day context is credited to Allingham and Sandmo (1972) they used economics of crime approach developed by Becker (1968) to explain taxpayers' behaviour and level of compliance. Tax compliance had been defined by many researchers. Thiga and Muturi (2015) defined tax compliance as the ability to fulfil tax payment obligation as required by the relevant tax laws. Saw (2017) defined tax compliance, as prompt and timely submission of tax returns along with tax liability declared, and payment of such liability to the tax authority. Ahmed and Kedir (2015) also stated that tax compliance is the degree at which taxpayers complies with tax laws and regulation as approved in a country. Furthermore, tax compliance is the willingness of taxpayers in obeying the relevant tax laws, declare the actual income and promptly pay the correct tax liabilities to the government (Sitardja \& Dwimulyani, 2016). 
Tax compliance can be in form of enforcement (tax authorities' influence) or by voluntary compliance. The enforcement compliance is achieved by function of penalty and detection while the voluntary compliance is achieved by taxpayer's willingness to comply with the relevant tax laws without any form of harassment or pressure from the tax authority. The enforced compliance is based on assumed power of authorities to pursue and bring to book the tax offenders or evaders while voluntary compliance is based on individual willingness to respect and exhibit trust in government or tax authorities (Muehlbacher \& Kirchler, 2010). According to Kirchler (2007) and Kirchler, Hoelzl, and Wahl (2008) tax compliance involved three things; these are trust in authorities, power of authorities and tax compliance.

Voluntary Tax Compliance: Voluntary tax compliance is taxpayer's willingness to prepare and file tax returns without any forms of pestering or coercing from the tax authority. Gangl, Hofmann, and Kirchler (2015) stated that it involves tax payment by the taxpayer without any form of enforcement but positive mutuality of the taxpayer. It is a form of respect to the tax laws by taxpayers, while the tax authorities, as service providers assist the taxpayers' in ensuring tax compliance with the provision of relevant tax laws. In complying with the relevant tax laws, the taxpayers at times enjoy loopholes opportunity in the tax laws to engage in tax avoidance by paying lesser amount of tax liabilities. The driver of voluntary tax compliance is trust. Modugu, Eragbhe, and Izedonmi (2012) stated that perception of government's accountability and transparency by the taxpayers enhances trust in government and this is instrumental factors to behavioural morals that lead to voluntary tax compliance.

Enforced Tax Compliance: Enforced tax compliance is achieved where taxpayers comply with relevant tax laws only by force or coercion from perceived higher power or authority. This is achieved through the deterrence effect of audits and fines by the tax authorities (Kirchler, 2007; Kirchler et al., 2008). This occurred where taxpayers complied with tax payments based on fear of audits and imposition of fines with forces, when there is no alternative to tax compliance. It arises where the taxpayers believe that tax payment can only be achieved by means of coercion and force by the state and its agencies (Kirchler et al., 2008).

Way of Achieving Tax Compliance: Tax compliance can be achieved through good tax education, trust between the government and the taxpayers, good tax administration system, tax counselling, and government cordial relationship with the media and advocacy group, for tax public relation and enlightenment. Besides, Appah and Peter (2013) stated tax compliance can be achieved by using the form of tax public relation and building tax consciousness environment among the taxpayers and the government (tax authorities).

Ola (2004) opined that taxpayers cannot comply with tax laws unless they have good knowledge of such laws. Thus, tax knowledge or education can be achieved through enlightenment and provision of publications that will help taxpayers in having seamless filling of tax returns and tax payment. Furthermore, tax compliance can also be achieved through tax counselling. This involve rendering services to taxpayers where necessary, in respect of matters related to tax issues that will enhance voluntary compliance. It also involves the interpretation of tax laws, and the procedure of steps by steps filling of tax returns by taxpayers. In addition, it also involves the form of tax guidance and training- this involve training of taxpayers and rendering of advisory services, especially on proper bookkeeping of accounting records and ways of submitting an accurate returns of statement of affairs for tax assessment to the tax authorities. Besides, tax award, prize or letter of recognition could be initiated, this involve proper recognition and appreciation of taxpayers who are honest, prompt and timely in making tax return to the tax authorities. The essence of all these is to enhance voluntary tax compliance at the informal sector in Nigeria for revenue generation and economic development of the country.

Informal sector: Informal sector is an unstructured economics activities in a country in which there are limited government regulations but substantially contribute to the household income, and the general growth and development of a country. It act as catalyst for job creation, revenue generation and means of reducing poverty in many developed and developing countries. Informal sector consist of micro, small and medium scale enterprises of small traders, caterers, artisans, professionals, domestic helpers, agriculturist/farmers, street vendors, entertainers, transporters and entrepreneurs. The sectors are responsible for the employment of many workers and contribute to the economy towards the social economic development and the Gross Domestic Product (GDP).

Although, the informal sector operator use the facilities provided by the government, which are predominantly financed with tax revenues generated from the relevant taxpayers in the formal sector. The informal sector is seen as contributing a large percentage of tax defaulters and evaders in developing countries, thereby contributing to leakages and losses in government revenue. According to ILO (2002) informal sector represent 65 percent of non-agricultural employment in Asia, 57 percent in America, 48 percent in North Africa and 72 percent in Sub-Saharan Africa. The first concept and definition of informal sector was launched in early 1970 s and this had given rise to various theoretical debates. The concept of informality came into being using two African countries, Ghana (informal income opportunity) by Hart (1971) and in Kenya (theory report of World employment performance by Richard Jolly and Hans Singer as main editors) (Charmes, 2012).

The Kenya mission report, popularised the definition of informal sector by International Labour Organisation in 1972 in which informality was defined as "a way of doing things", this was characterised by 
the following factors, ease of entry, small scale operators, unregulated and competitive markets, family ownership, reliance on indigenous resources, and labour intensive and adaptive technology skills. In line with this definition, Sparks and Barnett (2010) reported that informal sector has the highest share of most sectors of the economy across the World, informal businesses are found mostly in commerce, finance, manufacturing, haulage and logistics, transportation, agricultural, production, engineering and mining. The informal sector at time, are predominantly capitalised upon by politicians for cheap political gains, by relaxing certain vital laws and stoppages of tax imposition, during electioneering period in order to gain popularity and earn peoples votes to attain power. This is achieved because of the large numbers or participants of operators in the sector.

The three important factors for taxing the informal sectors are Revenue, Growth and Governance.

\subsubsection{Revenue}

The main benefit of taxing the informal sector is revenue generation. Therefore, taxing the informal sector is an act to increase government revenue, which is based on its largeness and its positive contribution to country's Gross Domestic Product (GDP) (Schneider \& Klinglmair, 2004). Informal sector forms the larger percentage of economics activities in many countries, taxing it, is avenue for generating tax revenues to the government for financing the country's annual budget. Schneider, Buehn, and Montenegro (2010) stated that informal sector taxation, represent a significant sources of revenue for depressed economy in order to survive and function as a government. Taxing the informal sector will also enhance and sustain tax morale, and increase the level of compliance among the informal sector participants (Terkper, 2003; Torgler, 2003). Besides, upon this laudable purposes, tax administrator at time, give little concerns to informal sector taxation (Fjeldstad, 2014). Some researchers are against informal sector taxation while some are in full support.

According to Keen (2012) taxing the informal sector should be less emphasised because the informal sector tax revenue is low with high cost of administration, it has regressive tax incidence and tax enforcement, where necessary, could lead to various form of harassment. Some school of thought are of the opinion that, taxing the informal sector is of utmost advantage to the government and his citizens. Since revenues to be generated from the sector at early stage are likely to be modest, as the tax revenues and tax rate will be very low, while the cost of collection will be high due to logistic and administrative cost such as cost of monitoring, assessment and collection. The low revenues at the early stage will propel some benefits such as bringing the informal sector participants into the tax net, thereby ensuring good data based for tax purposes, and increase in the level of tax compliance in the future.

\subsubsection{Growth}

The opportunity to formalise the informal sector into a formal form of business, will propel growth in the informal firms, which will add broader benefit to the existing firms in the formal sector (De Mel, McKenzie, \& Woodruff, 2012; McCulloch, Schulze, \& Voss, 2010). At times, firms in the informal sector, avoid payments of some costs and taxes, which might lead to exclusion from certain opportunities likes access to credit, government contracts, tax holiday and incentives, acquiring of modern technology, training, government grants and technical support that might be available for firms in the formal sector. Basley and Persson (2014) opined that small firms in the informal sector, has problems of economies of scale benefits and exportation opportunities, because they are not regulated by law. But with proper regulations and informal sector formalisation, firm's growth will be achieved as firms in the formal sector shows evidence of growth higher than that of the informal sector.

Gasper, Jaramillo, and Wingender (2016) aligned with this thought that formalisation of informal sector will contribute to the informal firms productivity, thereby leading to growth and increase in revenue generation. Joshi, Prichard, and Heady (2014b) stated that formalization can drive broader economic gains but just uncertain, whether or not small firms would be a beneficiary of this growth. Informal sector firms will formalise when the gains of formalisation is more than the costs of formalization, these cost are registration cost, regulations and cost of compliance. Furthermore, Rand and Torm (2012) affirmed that formalisation of small and medium enterprises into formal setting in Vietnam had positive impact on profits, investment and growth of those firms. Likewise, De Mel et al. (2012); McKenzie and Sakho (2010) agreed that formalization of informal sector firms enhances growth and increases the firms' profitability. Taking the growth expectation from formalisation into consideration, McKenzie and Woodruff (2006) argued that the benefit derivable from formalisation at time is minimal which might not be enough for the reason for firm's formalisation.

\subsubsection{Growth Constraint in the Informal Sector}

Taking the benefits and opportunities of growth or formalisation of the informal sector into consideration, especially for increase in tax revenues and level of tax compliance in Nigeria, it is saddled with the following challenges. (1) Infrastructure challenges- decay of infrastructure accessibility such as road, power, water, security and information technology has posed a great problems for growth. (2) Financial problems- lack of adequate collateral for loan, high cost attributable to borrowing, and limited credit facility. (3) Government regulation- stringent regulation for formalisation, delay in business registration, high tax rate applicable to firms in the formal sector, and procedural problems of getting business licenses and permits. (4) Security- lack 
of adequate security and protection, harassment from miscreant, land dispute and political imbalance. (5) Lack of adequate skills- high level of illiteracy, lack of training, lack of accounting, marketing and information knowledge. (6) Internal factors- Lack of modern machinery, non-accessibility to adequate raw materials, problem of competitive markets, stringent condition of entry, lack or working capital, stringent laws and its application, and other administrative and procedural problems.

\subsubsection{Governance}

One of the basic reason for taxing informal sector, and for enhancement of tax compliance, is the promotion of good governance through trust, transparency and accountability. According to Adekoya, Enyi, and Akintoye (2019); Joshi. et al. (2014) accountability influenced voluntary tax compliance, meaning that, government transparency and accountability on tax collections and its proper usage will enhance voluntary tax compliance. Demand for good governance will makes the government to be more responsive, honest, transparent and accountable to the citizens. This demand can be achieved through the theory of fiscal social contract, through this, the taxpayers will have the opportunity to ask questions from the government on the application of tax revenue. Prichard (2009) opined that tax payment by the informal sector participants is a form of social contract between them and the state government, thereby promoting legitimacy, accountability and good governance. In addition, the informal sector is the largest employer of labour in the country, therefore, taxing the sector will give the taxpayers the great opportunity of checkmating the operation of government. This will be achieved through the alliance or formation of pressure group by informal sector participants for purpose of collective bargaining and an agreement of block voting during election period. The essence of forming a pressure group or alliance is to aid a political voice against any form of maladministration of government. According to Meagher and Lindell (2013) pressure group or association in the informal sector at times determines the winner or loser in an election, this is to either foster interest in governance or used their votes as means of protesting and removing any bad government for any form of marginalisation.

\subsection{Methods of Taxing the Informal Sector}

Direct Presumptive Taxes: This is a form of taxation based on presumed income of an individual, who's his/her statement of affairs or income cannot be ascertained, due to the nature of business and lack of proper book of accounts. It involves the use of indirect method to ascertain informal sector tax liabilities, as against the usual method of tax computation based on taxpayer's statement of affair. This method will solve the problems normally faced in taxing small informal sector, from the challenges of high cost of collection by the tax authorities to high compliance costs for small informal sector operators. Presumptive tax method and rates differ from one country to another. According to Joshi et al. (2014) Ethiopia informal sector operators pay a presumptive tax on income plus $2 \%$ tax on turnover, Kenya and Ghana applies $3 \%$ flat rate on turnover to replace VAT and income tax while Tanzania operates a progressive tax system on turnover. Nigeria introduced presumptive tax in her tax system in 2011 as stated in Section 6 of PITA (amended). The targets taxpayers are small businesses, professional and individual operators in the informal sector. The Nigeria presumptive income tax assessment is a strategies for creating a tax system that will encourage and increase tax compliance in the informal sector.

Use of Association for Tax Collection: In Nigeria and most developing countries, there are various group of trade associations which are registered and guided by their rules, principles and internal regulations, which are enforced by their leaders and other constituted authorities. Trade association leadership in some countries, had been helpful in ensuring payment of various levies and trade licenses imposed on their members, such as development levy. The use of trade association, to build tax morale and compliance level among members could be helpful to government in revenue generation. The leadership of each trade association will act as collecting agent to the government, while the collection of these taxes will be tied to the neck of the leaders. Akeju (2018) opined that the informal sector taxation, could be achieved by using trade association leadership for revenue collection, acting as revenue agent of the government. The leadership of the trade association will ensure proper registration of members, and maintain proper data base for tax collection. The leadership of each association, will act as tax administrator for government, for tax collection, public enlightenment and tax compliance. The government and tax authority will only require, to put all form of measure in place for purpose of accountability by the leadership of trade association, while government on their own part must exhibit transparency and accountability for the use of the tax revenue, especially for the best interest of members and citizens at large. This method had been adopted in Ghana and it addressed challenges associated with tax collection from small and micro firms (Joshi \& Ayee, 2009).

\subsection{Lump Sum Presumptive Taxation or Fixed Lump Sum Based on Occupational Sector}

This is an assessment based on sectorial business and enterprises, it is payable by individual taxpayers engaging in such sector. The tax liability will be assessed based on certain criteria such as business size, number of employees, location, service capacity or production capacity and capital. This can be adopted where taxable incomes are difficult to monitor and assessed. The major challenge of this approach is honesty, where this is lacking, it will lead to corruption, argument and inconsistencies. 


\subsection{Challenges of Taxing the Informal Sector}

The low level of tax compliance in the informal sector in Nigeria can be attributed to various problems and challenges such as:

1. Poor understanding of tax laws.

2. Poor knowledge of the basic reason for paying tax.

3. Lack of proper keeping of accounting records.

4. Culture of tax evasion and avoidance.

5. Challenges of multiple taxation.

6. Corruption on the part of tax officials and government.

7. Lack of tax education and sensitisation by tax authorities.

8. Perception of infrastructural decay by taxpayers leading to cost and benefit analysis on tax collection from the informal sector.

9. Lack of adequate data base for informal sector participants with the absence of Tax Identification Number (TIN).

10. Capacity constraint and shortage of skill personnel, lack of modern equipment for tax administration, shortage of vehicles for tax authority for tax compliance monitoring and tax laws enforcement.

11. High level of political interference, where tax officials and politicians (government in power) jettison tax laws and revenue collection in favour of vote seeking from informal sector participants during the time of election.

\subsection{Methods of Promoting Tax Compliance in the Informal Sectors}

Tax compliance is key to collection of tax revenues, which is meant for economic growth and infrastructural developments of a country, therefore, there is need to ensure and promote good tax compliance behaviour in the informal sector. This tax compliance behaviour, can be achieved by taking into consideration the following factors:

\subsubsection{Transparency and Accountability}

Government transparency and accountability on tax revenue collected will build trust, this will enable relevant taxpayers in the informal sector to further oblige to voluntary tax compliance. According to Adekoya and Akintoye (2019) transparency is the prompt, clarity and timely provision of government information to the public for decision making. Omolehinwa and Naiyeju (2015) stated that lack of public accountability is a problem in developing countries, as this affects the level of tax compliance and revenue generation for financing government developmental projects and services. Accountability influenced voluntary tax compliance, therefore, making the details of tax collections and its usage available to citizens will enhance tax compliance (Adekoya et al., 2019). Kiow, Salleh, and Kassim (2017) reported that transparency in taxation is key to taxpayer's confidence, because, lack of confidence in the tax system and the government, might leads to tax evasion, dishonesty and fraud. Dishonesty and corruption by government on tax revenue reduces tax compliance behaviour, while accountability and transparency to tax system and tax revenues enhances positive tax compliance behaviour. In addition, Ortega, Ronconi, and Sanguinetti (2012) also affirmed that taxpayers, will be willing and voluntarily pay taxes when convinced that the government is transparent and accountable for taxes revenues. Exhibiting transparency by the government, provides the opportunity to enhance taxpayers' compliance levels, but where the taxpayer discovered that the government is dishonest, fraudulent and lack transparency in its activities, it leads to tax non-compliance and evasion (Fadjar, 2013).

\subsubsection{Trust}

High level of corruption on tax revenues and others, probably carried on by the government administrators and some of the tax officials, has created an atmosphere of mistrust between the relevant taxpayers in the informal sector and the government. Where trust is enhance between the government and the taxpayers, tax compliance will automatically be achieved and this will positively lead to positive collection of tax revenues from the informal sector. Adekoya and Akintoye (2019) reported that trust in government has positive relationship with taxpayer's voluntary tax behaviour and level of tax compliance. Torgler (2003b) opined that trust, perception of tax fairness and corruption have been seen as playing a vital role in tax compliance. In line with this, Feld and Frey (2007) affirmed that where government acts in manner of fairness, accord the citizens with transparency, and the government is perceived to be honest and fair, taxpayers will exhibit high level of voluntary tax compliance. Trust in government is one of the key factors that influences tax compliance level of taxpayers (Siahaan, 2012). Kirchler et al. (2008) reported that trust, is an opinion by taxpayers, that the government and tax authorities are honest, accountable and transparent, with evidence that tax revenue is use for the well-being of the citizens. This symbiotic relationship of trust between the tax authorities or government and the taxpayers will also leads to synergistic relationship. This occurred when the tax authorities or government, have the confidence that taxpayers will pay their taxes promptly and honestly, and taxpayers also has trust in the tax authorities and the government that tax revenues will be used in the best interest of the citizens. 


\subsubsection{Control of Corruption}

Fiscal corruption has become a major challenge that affect voluntary tax compliance. It destroy the social, economic and political environment of a country and ability to generate tax revenue. Corruption is a form of dishonest and fraudulent conduct undertaken by a person or organisation entrusted with power for private gain (Adekoya \& Enyi, 2020). Rosid, Evans, and Tran-Nam (2017) opined that corruption is perceived to be high in most developing countries and this affect taxpayer's perception of trust in government and willingness to pay tax. Syadullah and Wibowo (2015) also reported that, most developing countries suffered tax revenues losses due to bribery and corruption, this is achieved through a form of dishonest or immoral behaviour. Trust is linked to perception of corruption. Therefore, Nzotta (2007) reported that the major cause of tax evasion in Nigeria, is the high level of corrupt practices by the government officials at all levels of governance. This attitude has effect on informal sector taxpayers' willingness to pay tax, where public officials pocket tax revenues without any form of sanction, or where tax officials encourage bribing rather than allowing taxpayers paying the correct amount of tax to the government. (Adekoya \& Enyi, 2020) reported that control of corruption influenced taxpayers' voluntary tax compliance, it was recommended that government should ensure stiff strategies in controlling corruption on tax matters. Control of corruption can play an important role on informal sector tax compliance behaviour. Feld and Frey (2007) asserted that, honest and accountable governments will earn taxpayers' trust, such trust will translate to taxpayers' willingness to pay tax. Therefore, perception of government trust, tax fairness and lack of corruption have been reported as playing an important role in tax compliance behaviour (Torgler 2003c).

\subsubsection{Tax Education and Awareness}

Adequate tax enlightenment campaign in the media, the use of handbills and posters, billboards, road shows/mobile publicity and other mediums of publicity, will propel attitudinal changes toward tax compliance by citizens and relevant taxpayers in the informal sectors. Tax education and awareness is human in nature as it dictates how citizens understands, reacts and responds to reality of tax payment. The individual tax education and awareness ensure that taxpayers are willing to pay tax without being forced. Jackson and Milliron (1986) stated that education drives taxpayers' knowledge of either to comply or not, with relevant tax laws, knowledge enhances voluntary tax compliance. Lack of tax education and awareness is a major problem that works against tax collection in a country. The self-assessment system introduced by the tax authority, allows the taxpayer to register, calculate, report and pay tax liability but this required proper awareness and enlightenment. Therefore, level of compliance to tax revenue by citizens in a country, depends on the level of tax education and level of awareness by the citizens. Fatt and Khim (2011) stated that tax literacy and tax knowledge by individual taxpayer is importance to tax compliance, therefore, the success of self-assessment method of taxation depends on taxpayers' knowledge and understanding of the process of compliance. Kasum, Abdul-Kasum and Osemen (2013), cited in Lateef, Saheed, and Onipe (2015), reported that Nigeria has low level of tax awareness due to low level of tax publicity and tax education by the tax authorities. To overcome this problem in the Nigeria informal sector, Gasch (2014) advised that tax authorities should ensure continuous tax education programmes and public enlightenment for taxpayers on the basic knowledge of tax laws and benefit of tax payment. This exercise is to ensure continuous voluntary tax compliance and enhancing discharge of civic responsibilities.

\subsubsection{Infrastructural Development}

Infrastructural development enhances turnaround power in a country and its economies. Provision infrastructures such as good road and transportation network systems, constant power/electricity supplies for business productivity and economic activities, good telecommunication system for rapid sharing of information, security, and good justice and law, will propel better economics activities and better business trade. Linkage between the previous tax payment and infrastructural development drives citizens' response to future tax payment. Infrastructure are those capital projects or activities that will propel industrialisation and economy growth in a country. The existence and provision of these infrastructures will boost informal sector operators' confidence for better business activities, this will also boost their level of trust in the government, and will drive individual taxpayers in the informal sector towards positive response to tax payment and increase in the level of tax compliance. The end result is additional revenues to the government.

\subsubsection{Tax Law}

Tax law should be written in simple and clear language in order to be understood by all citizens. At times, understanding the tax laws is difficult and this mostly gives rise to different meaning and interpretations by the taxpayers and the tax authority. Tax laws and its complexity is one of the deterrents of taxpayer's behaviours and compliance, apart from tax system complexity and fiscal policy (Kirchler, Niemirowski, \& Wearing, 2006). Tax laws are to be obeyed for many reasons, while strict adherence to these laws as a lawabiding citizen is the right thing to do. Any form of ambiguity in the tax laws creates problems of application, such laws will be tagged as ambiguous where it becomes difficult to comprehend or acted upon (Long \& Swingen, 1991). Application of tax laws for informal sectors operators require better interpretation, by using 
simple and clear language that will aid taxpayers knowledge and understanding. Therefore, promoting fairness in the application of tax laws will enhance voluntary tax compliance (Adekoya et al., 2019). Promoting fairness in the informal sector is key to taxpayers response towards payment of tax while on the other hand, according to Batrancea, Nichita, and Batrancea (2012) lack of tax knowledge and tax laws gives the tax authority too much power, whereby tax decisions are taken to the detriment of the taxpayers and in favour of the government, this kill taxpayers moral and ability to comply.

\subsubsection{Quality of Tax Service}

Quality of tax service enjoy by individual taxpayers from the tax authorities or government is very critical to tax revenues collection and tax compliance behaviour. Quality of service is regarded as the degree of excellence or superiority which can either be objective or subjective. The types of service provided by tax authority to the taxpayers, determine the level of cordial relationship between the government and the informal sector operators. Taxpayers at times evaluate the level services provided by the tax authorities, such services as informative, interaction and transaction services. Jackson and Milliron (1986); Adekoya, Folajimi, and Ayodele (2020) opined that quality of tax service has a significant influence on taxpayers' compliance behaviour, while lack of tax awareness, tax education and poor tax service delivery is responsible for high level of tax non-compliance behaviour. Bojuwon and Obid (2015) classified quality of tax service into responsiveness, in formativeness and reliability. Responsiveness is the tax authority time frame of responses to several questions asked by the taxpayers, and how self-employed or informal sector taxpayers accomplishes tax goals within a shortest time frame. In formativeness refers to gravity and type of information, provided in tax authorities' website for informal sectors consumption, which are necessary for taxpayers' decision. Reliability is the quality of information provided, which informal sector operators can relied upon for tax decision making.

\subsubsection{Inter-Agency Collaboration}

Inter-agency collaboration through exchange of information and data, will assist the tax authority in integrating the informal sector into the national and state tax data based. This can be achieved through the integration of business registration agency (Corporate Affair Commission), Banks and Trade association with the federal and state tax authorities. This collaboration will assist the tax authority to capture the informal sector into the tax net and tax data base, with issuance of Tax Identification Number (TIN) to all operator in the sector.

\subsubsection{Capacity Building and Training}

The government has a role to play in the training and capacity building in the informal sector. This role can be in the form of organising seminar and workshop for informal sector operator, on basic knowledge of accounting and financial record keeping. This will expose them to the basic knowledge and importance of maintaining proper accounting records of their economic and business activities. This will lessen the tax authority burden, administrative problems and challenges of carrying out proper assessment of economic and business activities of informal sector firm, for purpose of determining of tax liabilities and further payment of tax by the informal sector taxpayers.

\subsection{Theoretical Review}

Comparative Treatment Theory: This theory was developed from equity theory. The theory anchored on fairness and equity among the taxpayers whether in the formal or informal sector. Therefore, individual compliance to tax laws is based on fairness and honesty in its application. According to Kirchler and Hoelzl (2006) equity and fairness in taxation build trust and mutual cooperation between taxpayers and tax authorities (government), this eventually leads to voluntary tax compliance. OECD (2010) opined that higher level of tax compliance will be achieved where the entire tax system is fair and honest. The willingness to pay tax increases when individuals in the informal sectors perceived fairness and equity in tax payment, since other taxpayers in the formal sector within the same country comply with tax payment. OECD (2010); Walsh (2012) categorised tax fairness into distributives, procedural and retributive. The distributive fairness is linked with fiscal exchange theory and it focus on exchange equity between the government and the taxpayers. This is taxpayers' perception of government fairness, justice and honesty on the application tax revenues. According to McKerchar and Evans (2009) addressing inequalities in fiscal exchange between the taxpayers and the government leads to voluntary tax compliance. The procedural and retributive fairness are linked with comparative treatment, this can be influenced by tax administration. Procedural fairness relates to perception of tax authority procedure and fairness in dealing with the taxpayers, while redistributive fairness relates to the perception of fairness on the application of penalties and sanctions on tax defaulters. Walsh (2012) reported that, the impact of perceived fairness of tax system, on tax compliance, is not only in respect of taxpayers but also relates to the tax burdens of the other taxpayers, as well as their compliance behaviour. 


\subsection{Empirical Review}

Obara and Nangih (2017) studied taxing informal sector and revenue generation in developing countries. Finding from the studied revealed that, taxing the informal sector will enhance revenue generation, and have positive influenced on the economy development of a nation. Akeju (2018) in his studied, informal sector and tax compliance: The role of association in South-West, Nigeria, recommends the integration of informal sector into formal sector to achieve growth strategy, as well as, the use of trade association leadership as government tax agent, for tax collection. All this is to enhance tax compliance and revenue generation. Dube and Casale (2016) studied the implementation of informal sector taxation, evidence from selected countries in Africa. The study suggested that, as much as tax revenue potential from the sector was initially low, due to administrative problems, therefore, adequate arrangement with various association leaderships in the informal sector, can be carried out. The association leaderships will act as tax agent for tax collection, this will improve revenue generation, administrative effectiveness and government-citizens cordial relationship.

In addition, Mahadea and Zogli (2018) studied constraint to growth in informal sector activities and formalisation. The study revealed that informal sector operators' contentment with their business activities, leads to reluctant feeling of transformation of business activities to formal setting, despite government encouragement, intervention and incentives packages provided to address enterprises constraints. Joshi et al. (2014) also viewed taxing the informal economy and the current state of knowledge and agendas for future research. The study looked into indirect benefit of taxing the informal sector in relation to economic growth, tax compliance and good governance. It was recommended that there is need for more research into cost and benefit of taxing the informal sector. Besides, Okoye, Akenbor, and Obara (2012) studied how to promote sustainable tax compliance in the informal sector in Nigeria, the study highlighted various problems associated with tax compliance in the informal sector in Nigeria, and suggested that government should address these problems to ensure tax compliance in the informal sector.

\section{Methodology}

The study employed exploratory research design. Relevant journals, books and other literatures in the field of accounting, taxation and finance relating to the subject matters were reviewed, analysed, conclusion drawn and recommendations were made.

\section{Conclusion and Recommendations}

\subsection{Conclusion}

Taxing the informal sector is very important to any developing country, this will achieved three things, boosting internally generated revenue, attainment of economic growth and provision of qualitative public governance. However, many researchers had reported on the benefit of generating tax revenue from the informal sector, but on growth and formalization, little had been done to show the empirical evidence that taxing the informal sector will enhance growth. On governance, literatures revealed that fiscal social contract brings about cordial relationship for future payment of tax or not. The three bases of taxing the informal sector, is assumed to build tax morale and increase tax compliance behaviour. Besides, government needs to expand its tax net, with much focus on the informal sector, as any further neglect of this sector to tax evasion and non-compliance, might dampen the moral of some individual taxpayers in the formal sector who had been paying tax willingly and regularly. Therefore, informal sector operators' perception of government's accountability, transparency, application of tax laws, infrastructural provision, and ability to minimise corruption would shape the tax morale of individual taxpayers, which would lead to tax compliance. The adoption of presumptive or use of association leadership for tax collection, will enhance increase in level of tax compliance and tax revenue to the government. In addition, tax administrative procedure should be overhauled, with the provision of necessary logistics for efficient and effective administration of tax laws.

\subsection{Recommendations}

Evidence gathered from various literatures, comes up with arrays of recommendations that informs policy decision. While some have been taken up by time and events, some need re-examination, but all in all the following are recommended, for achieving the opportunities of taxing the informal sector and attainment of increase in tax compliance.

1. Tax laws should be simplified for taxpayers knowledge and understanding in order to increase voluntary tax compliance.

2. Tax Identification Number (TIN) should be provided for all eligible taxpayers in the informal sector. This could be attached to accessing government, social and economic benefit such as education, health services, government contracts, business and banking transactions.

3. Establishment of tax courts to adjudicate on tax matters, this is to fast-track dispensation of tax justices.

4. The menace of multiple taxation should be curb and eliminated.

5. Qualified staff should be recruited and trained in the administration of tax matters.

6. Establishment of monitoring unit for proper enforcement of tax laws. 
7. Public enlightenment, education and publicity should be carried out on regular basis by the tax authorities.

8. Government should exhibit more level of accountability, trust and transparency in the application of tax revenue.

9. Inter-agency collaboration should be exploited for data gathering, and capturing of informal sector operators into the tax net and tax data base.

\section{References}

Adekoya, A. A., Oyebamiji, T. A., \& Lawal, B. A. (2019). Rule of law, moderated by trust in government and voluntary tax compliance behaviour among individual taxpayers in Nigeria. International Journal of Economics, Commerce and Mnagement, 7(10), 65-78.

Adekoya, A. A., Enyi, P. E., \& Akintoye, I. R. (2019). Government accountability and voluntary tax compliance behaviour in selected states in South-West, Nigeria. International Journal of Advanced Studies in Business Strategies and Management, 7(1), 114-135.

Adekoya, A. A., \& Akintoye, I. R. (2019). Government transparency moderated by trust in government and voluntary tax compliance behaviour in Nigeria. International Journal of Economics, Commerce and Management., 7(8), 524-644.

Adekoya, A. A., \& Enyi, P. E. (2020). Control of corruption, trust in government and voluntary tax compliance in SouthWest, Nigeria. Management Studies, Davidson Publication, 8(1), 84-97.

Adekoya, A. A., Folajimi, A. F., \& Ayodele, A. L. (2020). Quality of tax services, Moderated by trust in State Internal Revenue service and voluntary tax compliance behaviour among Individual taxpayers in South-West, Nigeria. Journal of Accounting, Business and Finance Research, 8(2), 47-57.Available at: https://doi.org/10.20448/2002.82.47.57.

Ahmed, A., \& Kedir, S. (2015). Tax compliance and its determinant the case of Jimma Zone, Ethiopia. International Journal of Research in Social Sciences, 6(2), 7-21.

Akeju, K. F. (2018). Informal sector and tax compliance: The role of associational membership in South West, Nigeria. International Journal of Applied Economics, Finance and Accounting, 3(1), 1-9.Available at: https://doi.org/10.33094/8.2017.2018.31.1.9.

Allingham, M., \& Sandmo, A. (1972). Income tax evasion: A theoretical analysis. Journal in Public Economics, 1(3-4), 323338.

Appah, E., \& Peter, E. (2013). A causality analysis between tax audit and tax compliance in Nigeria. European Journal of Business and Management, 5(2), 107-120.

Basley, T., \& Persson, T. (2014). Why do developing countries tax so little? The Journal of Economic Perceptive, 28(4), 99120.

Batrancea, L. M., Nichita, R. A., \& Batrancea, I. (2012). Understanding the determinants of tax compliance behavior as a prerequisite for increasing public levies. The Usv Annals of Economics and Public Administration, 12(15), 201-210.

Becker, G. S. (1968). Crime and punishment: An economic approach. Journal of Political Economy, 76(2), 169-217.

Bojuwon, M., \& Obid, S. (2015). Tax service quality: The mediating effect of perceived ease of use of the online tax system. Procedia-Social and Behavioral Sciences, $172(27), 2-9$.

Charmes, J. (2012). The informal economy worldwide: Trends and characteristics. Margin: The Journal of Applied Economic Research, 6(2), 103-132.Available at: https://doi.org/10.1177/097380101200600202.

Cobham, A. (2005). Tax evasion, tax avoidance and development. United Kingdom: Finance and Trade Policies Research Centre, University of Oxford.

De Mel, S., McKenzie, D., \& Woodruff, C. (2012). The demand for and consequences of formalisation among informal firms in Sri Lanka. World Bank Policy Research Working Paper 5991. Washington DC: World Bank.

Dube, G., \& Casale, D. (2016). The implementation of informal sector taxation. Evidence from selected African countries. eJournal of Tax Research, 14(3), 601-623.

Fadjar, O. P. (2013). The effect of tax transparency and trust on taxpayers' voluntary compliance. GSTF Journal on Business Revierw, 2(3), 4-8.

Fatt, C. K., \& Khim, E. W. S. (2011). A study of self-assessment tax system in Malaysia. Australian Journal of Basic and Applied Sciences, 5(7), 881-888.

Federal Ministry of Finance. (2017). National tax policy. FCT. Abuja, Nigeria: Federal Ministry of Finance.

Feld, L. P., \& Frey, B. S. (2002). Trust breed trust: How tax payers are treated. Economics of Governance, 3(2), 87-89.

Feld, L. P., \& Frey, B. S. (2007). Tax compliance as the result of a psychological tax contract: The role of incentives and responsive regulation. Law \& Policy, 29(1), 102-120.Available at: https://doi.org/10.1111/j.14679930.2007.00248.x

Fjeldstad, O. H. (2014). Tax and development: Donor support to strengthen tax systems in developing countries. Public Administration and Development, 34(3), 182-193.Available at: https://doi.org/10.1002/pad.1676.

Gangl, K., Hofmann, E., \& Kirchler, E. (2015). Tax authorities' interaction with taxpayers: A conception of compliance in social dilemmas by power and trust. New ideas in Psychology, 37, 13-23.Available at: https://doi.org/10.1016/j.newideapsych.2014.12.001.

Gasch, G. D. (2014). Tax awareness and compliant determinant in self-assessment system in Gambelia region: A case study of Gambelia revenue administration authority. A thesis submitted to ITCA, department of public administration. Ethiopia: Ethiopia Civil Yniversity.

Gasper, V., Jaramillo, L., \& Wingender, P. (2016). Tax capacity and growth:Is there a tapping point? IMF Working Paper No 16/234. International Monetary Fund.

Hart, K. (1971). Informal economy opportunities and urban employment in Ghana. Journal of Modern African Studies, 11 (3), 61-89. 
ILO. (1972). Employment, income and equality: A strategy for increasing productive employment in Kenya. International Labour Organisation. Geneva: International Labour Office.

ILO. (2002). Women and Men in the informal economy. International Labour Organisation. Geneva: International Labour Office.

ILO. (2014). Transitioning from informal to formaleconomy. Paper presented at the International Labour Conference. Geneva: International Labour Office.

Jackson, B. R., \& Milliron, V. C. (1986). Tax compliance research: Findings, problems, and prospects. Journal of Accounting Literature, 5(1), 125-165.

Joshi, A., Prichard, W., \& Heady, C. (2014b). Taxing the informal economy challenges, possibilities and remaining question. Institute of Development Studies (IDS), Working Papers No429.

Joshi, A., \& Ayee, J. (2009). Autonomy or organisation? Reforms in the Ghanaian internal revenue service. Public Administration and Development: The International Journal of Management Research and Practice, 29(4), 289302.Available at: https://doi.org/10.1002/pad.535.

Joshi.., A., Prichard, W., \& Heady, C. (2014). Taxing the informal economy: The current state of knowledge and agendas for future research. The Journal of Development Studies, 50(10), 1325-1347.Available at: https://doi.org/10.1080/00220388.2014.940910.

Keen, M. (2012). Tax and development- Again. In G. Zodrow and C Fuest, Critical issues in taxation in developing countries (pp. 13-44). Cambridge, MA: MIT Press.

Kiow, T. S., Salleh, M. F. M., \& Kassim, A. A. B. M. (2017). The determinants of individual taxpayers' tax compliance behaviour in peninsular Malaysia. International Business and Accounting Research Journal, 1(1), 26-43.Available at: https://doi.org/10.15294/ibarj.v1i1.4.

Kirchler, E. (2007). The economic psychology of tax behavior. Cambridge: Cambridge University Press.

Kirchler, E., Hoelzl, E., \& Wahl, I. (2008). Enforced versus voluntary tax compliance: The "slippery slope" framework. Journal of Economic Psychology, 29(2), $210-225$.

Kirchler, E., \& Hoelzl, E. (2006). Modelling taxpayers' behavior as a function of interaction between tax authorities and taxpayers. Hague: Boom Legal Publishers. The Hague.

Kirchler, E., Niemirowski, A., \& Wearing, A. (2006). Shared subjective views, intent to cooperate and tax compliance: Similarities between Australian taxpayers and tax officers. Journal of Economic Psychology, 27(4), 502517.Available at: https://doi.org/10.1016/j.joep.2006.01.005.

Lateef, O., Saheed, Z., \& Onipe, A. (2015). Institutional factors and personal tax compliance in Kaduna state, Nigeria. Journal of Research in Humanities and Social Sciences, 5(35), 146-157.

Long, S. B., \& Swingen, J. A. (1991). Taxpayer compliance: Setting new agenda for research. Law and Society Review, 25(2), 637-683.

Mahadea, D., \& Zogli, L.-K. J. (2018). Constraints to growth in informal sector activities and formalisation: A case study of Ghanaian slums. The Southern African Journal of Entrepreneurship and Small Business Management, 1O(1), 19.Available at: https://doi.org/10.4102/sajesbm.v10i1.130.

McCulloch, N., Schulze, G., \& Voss, J. (2010). What determines firms' decisions to formalise? Discussion Paper Series, No 13. University of Frieburg, Department of International Economic Policy.

McKenzie, D., \& Sakho, Y. (2010). Does it pay a firm to register for taxes? The impact of formality on firm profitability. Journal of Development Economics, 91(1), 15-24.

McKenzie, D. J., \& Woodruff, C. (2006). Do entry costs provide an empirical basis for poverty traps? Evidence from Mexican microenterprises. Economic Development and Cultural Change, 55(1), 3-42.Available at: https://doi.org/10.1086/505725.

McKerchar, M., \& Evans, C. (2009). Sustaining growth in developing economies through improved taxpayer compliance: Challenges for policy makers and revenue authorities. eJournal of Tax Research, 7(2), 171-201.

Meagher, K., \& Lindell, I. (2013). ASR forum: Engaging with African informal economies: Social inclusion or advance incorporation? African Studies Review, 56(3), 57-76.

Modugu, P. K., Eragbhe, E., \& Izedonmi, F. (2012). Government accountability and voluntary tax compliance in Nigeria. Research Journal of Finance and Accounting, 3(5), 69-76.

Muehlbacher, S., \& Kirchler, E. (2010). Tax compliance by trust and power of authorities. International Economic Journal, 24(4), 607-610.Available at: https://doi.org/10.1080/10168737.2010.526005.

National Bureau of Statistics. (2016). Formal and informal sector split of gross domestic product-2015. Abuja, Nigeria: Nigerian National Bureau of Statistics.

Nzotta, S. M. (2007). Tax evasion problems in Nigeria: A critique. The Nigerian Accountant, 40(2), 40-43.

Obara, L. C., \& Nangih, E. (2017). Taxing the informal sector and revenue generation in developing countries: An empirical investigation from Rivers State of Nigeria. Journal of Accounting and Financial Management, 3(1), 47-55.

OECD. (2010). Understanding and influencing taxpayers' compliance behavior. Paris, France: OECD Center for Tax Policy and Administration.

Okoye, P., Akenbor, C. O., \& Obara, L. C. (2012). Promoting sustainable tax compliance in the informal sector in Nigeria. AFRREV IJAH: An International Journal of Arts and Humanities, 1(1), 40-54.

Ola, C. S. (2004). Income tax law and practice in Nigeria. Ibadan, Nigeria: Heinemann Educational Publishing Company.

Olowookere, J., \& Fasina, H. (2013). Taxpayers' education: A key strategy in achieving voluntary compliance in Lagos State, Nigeria. European Journal of Business and Management, 5(10), 146-154.

Omolehinwa, E. O., \& Naiyeju, J. K. (2015). Government accounting in Nigeria: An IPSAS approach (1st ed.). Lagos, Nigeria: Pumark Nigeria Limited.

Ortega, D., Ronconi, L., \& Sanguinetti, P. (2012). Reciprocity and willingness to pay tax: Evidence from survey experiment in Latin America. Economics, 16(2), 55-87.

Prichard, W. (2009). The politics of taxation and implications for accountability in Ghana 1981-2008. IDS Working Paper 330. Brighton: Institute of Development Studies. 
Rand, J., \& Torm, N. (2012). The benefits of formalization: Evidence from Vietnamese manufacturing SMEs. World Development, 4O(5), 983-998.Available at: https://doi.org/10.1016/j.worlddev.2011.09.004.

Rosid, A., Evans, C., \& Tran-Nam, B. (2017). Perception of corruption and intentional non-compliance behavior: Policy implication for developing countries. Paper presented at the Paper Presented at the 5th Annual Tax Administration Research Centre Workshop. University of Exeter.

Saw, S. (2017). Does frequency of audits improve tax compliance? South East Asia Journal of Contemporary Business, Economics and Law, 14(1), 18-26.

Schneider, F., Buehn, A., \& Montenegro, C. (2010). Shadow economies all over the world: New estimates for 162 countries from 1999-2007. World Bank Policy Research Working Paper No. 5356. Washington, DC: The World Bank.

Schneider, F., \& Klinglmair, R. (2004). Shadow economies around the world: What do we know? Working Paper, Department of Economics, No 0403. Linz: Johanness Kepler University.

Siahaan, F. O. (2012). The influence of tax fairness and communication on voluntary compliance: Trust as intervening variable. International Journal of Business and Social Science, 3(21), 1-10.

Sitardja, M., \& Dwimulyani, S. (2016). Analysis about the Influences of Good Public Governance, Trust toward Tax Compliance on Public Companies that Listed in Indonesian Stock Exchange. OIDA International Journal of Sustainable Development, 9(09), 35-42.

Slahaan, F. O. (2012). The influence of tax fairness and communication on voluntary compliance: Trust as an intervening variable. International Journal of Business and Social Science, 3(21), 191-198.

Sparks, D. L., \& Barnett, S. T. (2010). The informal sector in Sub-Saharan Africa: Out of the shadows to foster sustainable employment and equity? International Business \& Economics Research Journal (IBER), 9(5), 1-10.Available at: https://doi.org/10.19030/iber.v9i5.563.

Syadullah, M., \& Wibowo, T. (2015). Governance and tax revenue in Asean countries. Journal of Social and Development Sciences, 6(2), 76-88

Terkper, S. (2003). Managing small and medium size taxpayers in developing economies. Tax Note International, 1(1), 211234.

Thiga, M., \& Muturi, W. (2015). Factors that influence Compliance with tax laws among small and medium sized Enterprises in Kenya. International Journal of Scientific and Research Publications, 5(6), 1-12.

Torgler, B. (2003). Tax morale, rule, governed behavior and trust. Constitutional Political Economy, 14(2), 119-140.

Torgler, B. (2003b). To evade tax or not to evade: That is the question. Journal of Social Economics, 32(3), 283-302.

Torgler, B. (2003c). Beyond punishment: A tax compliance experiment with taxpayers in Costa Rica. Revista de Analisis Economico, 18(1), 27-56.

Walsh, K. (2012). Understanding taxpayer behavior- New opportunities for tax administration. The Economic and Social Review, 43(8), 451-475.

Williams, C. C., \& Krasniqi, B. (2017). Evaluating the individual and country level variation in tax morale. Journal of Economics Studies, 44(5), 816-832. 